\title{
Characterization of muscarinic receptors mediating vasodilation in rat perfused kidney
}

\author{
Manfrid Eltze ${ }^{a}$, Brigitte Ullrich ${ }^{a}$, Ernst Mutschler ${ }^{b}$, Ulrich Moser ${ }^{b}$, Edwin Bungardt ${ }^{b}$, \\ Thomas Friebe ${ }^{b}$, Christian Gubitz ${ }^{b}$, Reinhold Tacke ${ }^{c}$ and Günter Lambrecht ${ }^{b}$ \\ a Department of Pharmacology, Byk Gulden Pharmaceuticals, 78467 Konstanz, Germany, b Department of Pharmacology, University of Frankfurt, \\ Theodor-Stern-Kai 7, 60590 Frankfurt / M, Germany and ' Institute of Inorganic Chemistry, University of Karlsruhe, Engesser Strasse, \\ 76128 Karlsruhe, Germany
}

Received 31 December 1992, revised MS received 13 April 1993, accepted 27 April 1993

\begin{abstract}
The muscarinic receptor mediating vasodilation of resistance vessels in the rat isolated, constant-pressure perfused kidney (preconstriction by $10^{-7} \mathrm{M}$ cirazoline) was characterized by subtype-preferring agonists and selective antagonists. The agonists produced vasodilation with the following rank order of potency: arecaidine propargyl ester $(\mathrm{APE})>5$-methylfurtrethonium $=$ methacholine $=$ oxotremorine $>(S)$-aceclidine $>$ arecaidine 2-butyne-1,4-diyl bisester $>4-\mathrm{Cl}-\mathrm{McN}-\mathrm{A}-343=(\mathrm{R})$-nipecotic acid ethyl ester $=\mathrm{N}$-ethyl-guvacine propargyl ester $\sim(\mathrm{R})$-aceclidine $=(\mathrm{S})$-nipecotic acid ethyl ester $>\mathrm{McN}$-A-343. Agonist-induced vasodilation disappeared after destruction of the endothelium with detergent. Highly significant correlations of agonist potencies for vasodilation were found between rat kidney and guinea-pig ileum submucosal arterioles as well as agonist potencies at smooth muscle muscarinic $\mathrm{M}_{3}$ receptors of the guinea-pig ileum. The rank order of antagonist potencies (4-diphenylacetoxy-Nmethylpiperidine methiodide (4-DAMP) $>$ (R)-hexahydro-difenidol $\sim$ hexahydro-sila-difenidol $>$ pirenzepine $\sim$ p-fluorohexahydro-sila-difenidol $\sim$ himbacine $\sim$ AF-DX $384 \sim$ AQ-RA $741>$ (S)-hexahydro-difenidol) to attenuate vasodilation to APE in rat kidney, correlated significantly with affinities at $M_{3}$ receptors in submucosal arterioles and in smooth muscle of the guinea-pig ileum, but differed from those at $M_{1}$ and $M_{2}$ receptors in rabbit vas deferens. The agonist and antagonist potencies suggest that vasodilation elicited by muscarinic stimuli in endothelium-intact rat renal vasculature is mediated by functional muscarinic $\mathrm{M}_{3}$ receptors.
\end{abstract}

Kidney (perfused, rat); Muscarinic receptor agonists; Muscarinic receptor antagonists; Arterioles (submucosal); Ileum; Atrium; Vas deferens; Videomicroscopy (guinea pig)

\section{Introduction}

Muscarinic receptors have been classified on the basis of pharmacological evidence into at least three subtypes termed $\mathbf{M}_{1}, \mathbf{M}_{2}$ and $\mathbf{M}_{3}$ (Hulme et al., 1990). Molecular biological evidence indicates that at least five genes exist that encode $m_{1}-m_{5}$ receptors (Hulme et al., 1990). The $m_{1}-m_{3}$ gene products correspond to the $M_{1}-M_{3}$ receptors (Hulme et al., 1990; Waelbroeck et al., 1990; Dörje et al., 1991b), whilst pharmacological candidates for the $\mathrm{M}_{4}$ receptor have also been tentatively identified in rat striatum, rabbit lung and some cell lines (Hulme et al., 1990; Lazareno et al., 1990; Waelbroeck et al., 1990; Dörje et al., 1991a). A functional equivalent of the $m_{5}$ gene product has yet to be identified.

Correspondence to: M. Eltze, Department of Pharmacology, Byk Gulden Pharmaceuticals, 78467 Konstanz, Germany. Tel. 49.7531.842617, fax 49.7531.842413.
Each of the three subtypes, $M_{1}, M_{2}$ and $M_{3}$, has been demonstrated to exist in vascular preparations from different species depending on the tissue and function examined (for a recent review, see Eglen and Whiting, 1990). In general, $\mathbf{M}_{3}$ receptors mediate endothelium-dependent relaxation, whereas $\mathbf{M}_{1}$ receptor stimulation causes contraction of e.g. canine saphenous and femoral veins. Stimulation of prejunctional $\mathbf{M}_{2}$ receptors appears to inhibit sympathetic outflow in vascular preparations from a number of anatomical locations from different species. Contraction may also occur due to stimulation of $\mathbf{M}_{2}$ (e.g. in rabbit aorta; Jaiswal et al., 1991) and $M_{3}$ receptors (e.g. bovine and porcine coronary artery; Eglen and Whiting, 1990).

Studies on vascular resistance in the rat isolated perfused kidney have provided evidence that nitric oxide (NO) mediates the vasodilator response to acetylcholine (Bhardwaj and Moore, 1988; Burton et al., 1990). Muscarinic receptor sites in rat kidney labelled with $\left[{ }^{3} \mathrm{H}\right]$ quinuclidinyl benzilate $\left(\left[{ }^{3} \mathrm{H}\right] \mathrm{QNB}\right)$ were 
located primarily within the smooth muscle of the vascular tree and to a lesser extent within the cortical and medullary tubules (De Michele et al., 1989). Autoradiographic analysis has located $\mathbf{M}_{3}$ receptors in glomeruli but not in tubules of rat kidney (Rodrigues de Miranda et al., 1989) Recently, muscarinic receptors in rat kidney cortex have been characterized to be of the $\mathrm{M}_{3}$ subtype (Blankesteijn et al., 1993). However, no detailed functional characterization of the muscarinic receptor subtype(s) involved in the various renal effects evoked by muscarinic stimuli in this species has been performed so far.

The aim of the present study was to characterize the muscarinic receptor responsible for the endotheliumdependent vasodilation in rat kidney. For this purpose, the ability of a series of subtype-preferring agonists to elicit relaxation as well as the potency of selective antagonists to inhibit this muscarinic effect were determined in the isolated, perfused rat kidney. Agonist and antagonist potencies were compared with those obtained at $M_{3}$ receptors in guinea-pig ileum submucosal arterioles (Bungardt et al., 1992), at $M_{1}$ and $M_{2}$ receptors in rabbit vas deferens (Eltze, 1988), as well as at atrial $M_{2}$ and ileal $M_{3}$ receptors of the guinea-pig.

\section{Materials and methods}

\subsection{Rat isolated perfused kidney}

The experiments were performed on kidneys taken from normotensive rats (Sprague-Dawley, male, 400$450 \mathrm{~g}$, Wiga, Sulzfeld, Germany), similarly to the method described previously (Eltze et al., 1991). Briefly, after the aorta adjacent to the left renal artery had been cannulated and the abdominal vena cava cut, the kidney was removed and perfused at a constant pressure of $100 \mathrm{~cm} \mathrm{H}_{2} \mathrm{O}$ with prewarmed $\left(37^{\circ} \mathrm{C}\right)$ Tyrode solution of the following composition (mM): $\mathrm{NaCl}$ 137.0, $\mathrm{KCl} 2.7, \mathrm{CaCl}_{2} 1.25, \mathrm{MgCl}_{2} 1.1, \mathrm{NaHCO}_{3} 12.0$, $\mathrm{NaH}_{2} \mathrm{PO}_{4} 0.42$, Ca-EDTA 0.026, glucose 5.6, additionally containing L-arginine hydrochloride 0.03 and indomethacin 0.01 , gassed with a mixture of $95 \% \mathrm{O}_{2}-5 \%$ $\mathrm{CO}_{2}$. The prerenal perfusate flow was measured continuously using an electromagnetic flowmeter.

\subsubsection{Agonist potency}

Each experiment consisted of a 40-min equilibration period during which renal perfusate flow stabilized at $17.4 \pm 3.6 \mathrm{ml} / \mathrm{min}$ (mean \pm S.D., $\mathrm{n}=51$ ). Following this period, a second reservoir containing the vasoconstrictor agent, cirazoline $\left(10^{-7} \mathrm{M}\right)$, which was an appropriate concentration to reduce renal perfusate flow between $62-83 \%$ (resulting flow $=4.8 \pm 1.9 \mathrm{ml} / \mathrm{min}$; mean \pm S.D., $n=51$ ), was connected via a three-way stopcock to continuously perfuse the kidney. Once the resulting constriction had stabilized, increasing doses of the muscarinic agonists (100 $\mu \mathrm{l}$ aqueous bolus) were injected within $2 \mathrm{~s}$ into the renal inflow tract and the resulting vasodilation was recorded. The $-\log E D_{50}$ values (mol) were determined graphically from semilogarithmic plots. At the end of drug administration the maximal effect was determined by bolus injection of $3 \times 10^{-7} \mathrm{~mol}$ arecaidine propargyl ester (APE). The perfusion was then changed to Tyrode solution without vasoconstrictor. The kidneys were repeatedly constricted in cycles of $45 \mathrm{~min}$. Each preparation was used to evaluate the responses of the renal vasculature to maximally six different agonists in random order, provided that (a) the vasoconstriction in response to $10^{-7}$ $M$ cirazoline could be exactly reproduced and (b) the vasodilator response to bolus injections of $3 \times 10^{-7}$ mol APE remained stable. No significant time-dependent changes in the vascular responses to the agonists could be detected.

\subsubsection{Removal of endothelium}

Vascular endothelium was removed by perfusion of the kidney for $5 \mathrm{~min}$ with Tyrode solution containing 3-[(3-cholamidopropyl)-dimethylammonio]-1-propanesulfonate (CHAPS, $0.2 \mathrm{mg} / \mathrm{ml}$ ) similar to the method described by Bhardwaj and Moore (1988). The degree of endothelial damage was verified functionally by the inability of bolus injections of muscarinic agonists to elicit a vasodilation of more than $7 \%$ in cirazoline-preconstricted $\left(10^{-7} \mathrm{M}\right)$ organs. Functional integrity of the vascular smooth muscle after CHAPS treatment was investigated with the endothelium-independent vasodilator, nitroprusside $\left(10^{-7} \mathrm{~mol}\right)$.

\subsubsection{Antagonist potency}

The increase in renal flow due to bolus injections of $5 \times 10^{-9}$ mol APE ( $=\mathrm{ED}_{70}$ of its own maximal effect) during perfusion of the kidneys with cirazoline $\left(10^{-7}\right.$ $M)$ in the absence of the muscarinic antagonists was taken to be $100 \%$. The percentage inhibition of this effect in the presence of increasing concentrations of the antagonists perfused together with cirazoline for 20 min was calculated. Thus, complete individual concentration-response curves for an antagonist were generated in five or six kidneys, enabling calculation of an $\mathrm{EC}_{50}$ value, i.e., the molar concentration for half-maximal antivasodilator effect.

\subsection{Guinea-pig isolated ileum submucosal arterioles}

Submucosal plexus preparations were obtained from the small intestine of guinea-pigs as described previously (Bungardt et al., 1992). Briefly, the preparations were perfused continuously at $8-10 \mathrm{ml} / \mathrm{min}$ with Tyrode solution gassed with $95 \% \mathrm{O}_{2}-5 \% \mathrm{CO}_{2}$ at $32-36^{\circ} \mathrm{C}$ (composition, see under 2.3). The outside diameter of 
submucosal arterioles was monitored by using a computer-assisted videomicroscopic system (Diamtrak). Muscarinic agonists were applied cumulatively by superfusion to vessels previously constricted by $10^{-5} \mathrm{M}$ (-)-noradrenaline. The apparent agonist potency was expressed as its $\mathrm{EC}_{50}$ value, i.e. the molar concentration inducing $50 \%$ of the individual maximal vasodilation.

\subsection{Guinea-pig isolated left atrium and ileum}

Guinea-pigs (300-400 g) of either sex were killed by cervical dislocation. The removed left atrium was set up in a 6-ml organ bath under $0.5 \mathrm{~g}$ tension in oxygenated $\left(95 \% \quad \mathrm{O}_{2}-5 \% \quad \mathrm{CO}_{2}\right)$ Tyrode solution at $32^{\circ} \mathrm{C}$ composed of (mM): $\mathrm{NaCl} 137.0, \mathrm{KCl} 2.7, \mathrm{CaCl}_{2} 1.8$, $\mathrm{MgCl}_{2} 1.05, \mathrm{NaHCO}_{3} 11.9, \mathrm{NaH}_{2} \mathrm{PO}_{4} 0.42$ and glucose 5.6 , and was paced electrically $(2 \mathrm{~Hz}, 3 \mathrm{~ms}, 5 \mathrm{~V})$ by means of platinum electrodes. The negative inotropic effect of the muscarinic agonists was measured as change in isometric tension and $\mathrm{pD}_{2}$ values $\left(-\log \mathrm{EC}_{50} \mathrm{~s}\right)$ were calculated. In antagonist studies, APE was used as agonist, the antagonists being equilibrated with the atria for at least $30 \mathrm{~min}$ (Feifel et al., 1990).

Strips of ileal longitudinal smooth muscle suspended in Tyrode solution (composition as used for the atrium) were maintained at $32^{\circ} \mathrm{C}$ and gassed with $95 \% \mathrm{O}_{2}-5 \%$ $\mathrm{CO}_{2}$ under a resting load of $0.5 \mathrm{~g}$ (Feifel et al., 1990). Isotonic contractions were elicited by cumulative addition of muscarinic agonists at 30-min intervals and $\mathrm{pD}_{2}$ values ( $-\log \mathrm{EC}_{50} \mathrm{~s}$ ) were determined graphically from semi-logarithmic plots. For assessment of antagonist affinity, concentration-response curves to acetylcholine or APE were obtained in the absence and presence of the antagonists equilibrated with the tissue for at least $20 \mathrm{~min}$.

Both in guinea-pig atrium and ileum, apparent efficacies (intrinsic activity, i.a. values) were determined by comparing the maximum response to the agonists with that to APE (i.a. = 1.00).

\subsection{Rabbit vas deferens}

Male New Zealand white rabbits were killed by i.v. injection of pentobarbital sodium $(60 \mathrm{mg} / \mathrm{kg})$ and exsanguination. Vasa deferentia were removed and divided into four segments, two prostatic portions of 1 $\mathrm{cm}$ and two epididymal portions each approximately $1.5 \mathrm{~cm}$ in length. Each tissue was folded in two over a platinum electrode in a $10-\mathrm{ml}$ organ bath and connected via a thread to a force-displacement transducer. A second platinum ring electrode was placed at the top of the bathing fluid for continuous field stimulation $(0.05 \mathrm{~Hz}, 0.5 \mathrm{~ms}, 30 \mathrm{~V})$. The bathing fluid (composition in $\mathrm{mM}: \mathrm{NaCl} 118.0, \mathrm{KCl} 4.7, \mathrm{CaCl}_{2} 2.5, \mathrm{MgSO}_{4} 0.6$,
$\mathrm{KH}_{2} \mathrm{PO}_{4}$ 1.2, $\mathrm{NaHCO}_{3} 25.0$, glucose 11.1 , yohimbine 0.001 ) was maintained at $31^{\circ} \mathrm{C}$ and gassed with $95 \%$ $\mathrm{O}_{2}-5 \% \mathrm{CO}_{2}$. A resting tension of $0.75 \mathrm{~g}$ was applied and neurogenic twitch contractions were measured isometrically and recorded on a multi-channel recorder (Eltze, 1988).

Agonist potencies ( $\mathrm{pD}_{2}$ values) and apparent efficacies (i.a. values) at muscarinic $M_{1}$ receptors in rabbit vas deferens were determined on close prostatic segments suspended in the nutrient solution mentioned above, with the exception that the $\mathrm{CaCl}_{2}$ concentration was reduced to $1.8 \mathrm{mM}$. 4-Cl-McN-A-343 was used as reference agonist.

Antagonists affinities for $\mathrm{M}_{1}$ and $\mathrm{M}_{2}$ receptors were obtained from concentration-response curves either to McN-A-343 for inhibition ( $M_{1}$ receptors) or to carbachol for potentiation $\left(\mathrm{M}_{2}\right.$ receptors) of neurogenic twitch contractions in the absence and presence of antagonists (45-min exposure time) (Eltze, 1988).

\subsection{Data analysis}

For the assessment of antagonist affinity in rabbit vas deferens and guinea-pig atrium and ileum, $\mathrm{EC}_{50}$ values of agonists were determined for the control and the antagonist-shifted concentration-response curves using at least four different antagonist concentrations (log interval $=0.48$ ). Each concentration of an antagonist was tested 3-4 times and the ratios of agonist molar $\mathrm{EC}_{50}$ values obtained in the absence and presence of antagonists were calculated. Schild plots were made, using linear regression by the method of least squares, to estimate the slope of the regression lines (Arunlakshana and Schild, 1959). $\mathrm{pA}_{2}$ values were obtained from Schild plots in which the slopes of the regression lines were constrained to 1.00 (Tallarida et al., 1979). In those few cases (table 2) where the slopes differ significantly from unity $(P<0.05)$, the $\mathrm{pA}_{2}$ values should be regarded as a purely experimental quantity.

\subsection{Linear regressions}

Linear regressions were calculated by the method of least squares in order to determine the correlation coefficient $r$ and the slope of regression $\beta$. Significance of differences of the slope from unity was assessed with t-tests.

\subsection{Drugs}

Arecaidine propargyl ester hydrobromide (APE), guvacine propargyl ester hydrobromide (GPE), guvacoline hydrobromide, $\mathrm{N}$-ethyl-guvacine propargyl ester hydrobromide (NEN-APE), arecaidine 2-butyne-1,4diyl bisester p-toluene sulfonate (bis-ABE), (R)- 


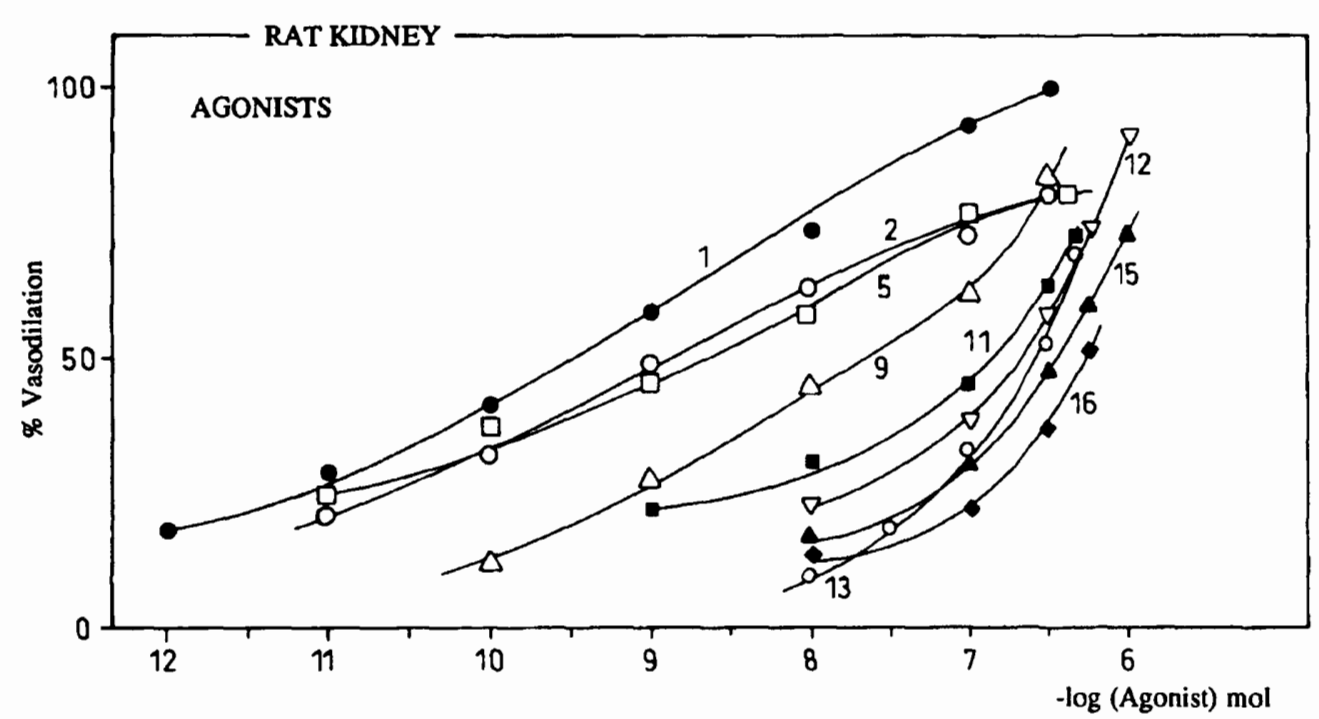

Fig. 1. Dose-response curves of muscarinic agonists to evoke renal vasodilation in constant-pressure perfused rat kidney during continuous perfusion of $10^{-7} \mathrm{M}$ cirazoline. Given are means of $n=5-7$ experiments (S.D. $<9 \%$, not shown). Ordinate: percent vasodilation related to the maximum effect to APE $\left(3 \times 10^{-7} \mathrm{~mol}\right)$ in the same preparation. Abscissa: - log mol of the agonists administered by bolus injection. For the sake of clarity, not all agonists investigated (with numbering in table 1) are depicted.

aceclidine perchlorate and (S)-aceclidine hydrobromide, 4-[[N-(4-chlorophenyl)-carbamoyl]oxy]-2-butynyltrimethylammonium iodide (4-Cl-McN-A-343), hexahydro-sila-difenidol hydrochloride (HHSiD) and its p-fluoro analogue (p-F-HHSiD), (R)- and (S)-enantiomers of hexahydro-difenidol hydrochloride [(R)-HHD and (S)-HHD] were synthesized in our laboratories. Oxotremorine sesquifumarate (Merck, Darmstadt, Germany). (R)- and (S)-nipecotic acid ethyl ester tartrate ((R)- and (S)-NAEE) were kindly donated by Prof. Krogsgaard-Larsen (Copenhagen, Denmark). Nuvenzepine hydrochloride (Dompé Pharmaceuticals, Milan, Italy). Mequitamium iodide (Laboratori Guidotti, Pisa,
Italy). 4-[[N-(3-Chlorophenyl)carbamoyl]oxy]-2-butynyltrimethylammonium chloride (McN-A-343) was purchased from RBI (Cologne, Germany). ( \pm )-Methacholine chloride (EGA Chemie, Steinheim, Germany). Pirenzepine dihydrochloride, ( \pm )-6-chloro-5,10-dihydro-5-[(1-methyl-4-piperidinyl)acetyl]-11H-dibenzo[b,e]diazepin-11-one hydrochloride (UH-AH 37), ( \pm )5,11-dihydro-11-[[[2-[2-((dipropylamino)methy])-1-piperidinyl]ethyl]aminocarbonyl]-6H-pyrido(2,3-b)(1,4)benzodiazepin-6-one (AF-DX 384), 11-[[4-[4-(diethy]amino)butyl)-1-piperidinyl]acetyl]-5,11-dihydro-6H-pyrido(2,3-b)(1,4)-benzodiazepin-6-one (AQ-RA 741) (Prof. B. Wetzel, Thomae, Biberach, Germany). Him-

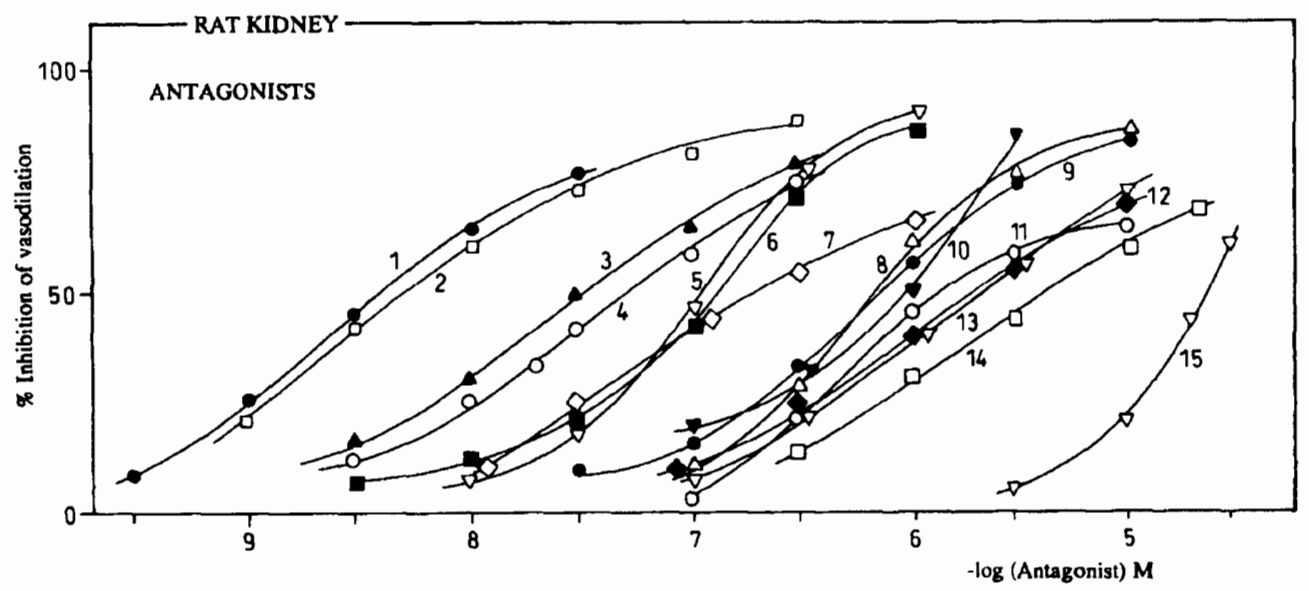

Fig. 2. Concentration-response curves for inhibition by muscarinic antagonists of renal vasodilation induced by bolus injection of $5 \times 10^{-9} \mathrm{~mol}$ APE during continuous cirazoline perfusion $\left(10^{-7} \mathrm{M}\right)$ in rat kidney. Given are means of $n=5-6$ experiments (S.D. $<10 \%$, not shown). Ordinate: $\%$ inhibition of APE-induced vasodilation. Abscissa: $-\log M$ of the antagonists equilibrated with the kidney for 20 min. Numbering of the antagonists refers to table 2 . 
bacine hydrochloride was kindly donated by Prof. W.C. Taylor (University of Sydney, Australia). Idaverine (Duphar BV, Weesp, The Netherlands). ( \pm )-Telenzepine dihydrochloride, 4-diphenylacetoxy-N-methylpiperidine methiodide (4-DAMP), 5-methylfurtrethonium iodide (MeFur) (Byk Gulden, Konstanz, Germany). Cirazoline hydrochloride (Synthélabo, Paris, France). Disodium nitroprusside (Schwarz, Monheim, Germany). rac-Cromakalim (Smith Kline Beecham, U.K.). All other drugs (arecoline hydrobromide, $( \pm$ )muscarine chloride, carbamoylcholine chloride (carbachol), hexamethonium bromide, tetrodotoxin, atropine sulfate, papaverine hydrochloride and 3-[(3cholamidopropyl)-dimethylammonio]-1-propanesulfonate (CHAPS)) were purchased from Sigma (Munich, Germany).

\section{Results}

\subsection{Rat perfused kidney}

\subsubsection{Effect of drugs on non-preconstricted kidneys}

Without vasoconstrictor stimuli, bolus injection of papaverine (up to $10^{-6} \mathrm{~mol}$ ) proved to be ineffective. Injection of other smooth muscle relaxants, e.g. nitroprusside (up to $10^{-6} \mathrm{~mol}$ ) and cromakalim (up to $10^{-7}$ mol) into the renal inflow tract did not increase perfusion flow of the kidneys by more than $5 \%$, indicating an essential absence of intrinsic vascular tone. None of the muscarinic agonists and antagonists listed in tables 1 and 2, respectively, when injected into the renal inflow tract up to $10^{-7} \mathrm{~mol}$, enhanced or diminished basal flow by more than $7 \%$.

\section{TABLE 1}

Potency of muscarinic agonists to elicit vasodilation in perfused rat kidney preconstricted with cirazoline $\left(10^{-7} \mathrm{M}\right)$ and their potency $(\mathrm{pD} 2$ values) at muscarinic $M_{3}$ receptors in guinea-pig ileum (GPI), $M_{1}$ receptors in rabbit vas deferens (RVD) and $M_{2}$ receptors in guinea-pig atrium (GPA).

Given are means with $95 \%$ confidence limits or S.D. of $n=6-7$ kidneys and $n=6-12$ experiments for those in the other preparations. Maximal effects in rat kidney and apparent efficacies (i.a. values) in guinea-pig ileum and atrium are related to APE. Apparent efficacies (i.a. values) in rabbit vas deferens are related to the total inhibition of twitch amplitude.

\begin{tabular}{|c|c|c|c|c|}
\hline \multirow[t]{2}{*}{ Drug } & \multirow{2}{*}{$\begin{array}{l}\text { Rad kidney } \\
-\log E D_{50}(\mathrm{~mol}) \\
(\% \max . \text { effect })\end{array}$} & \multicolumn{3}{|l|}{$\mathrm{pD}_{2}$ (i.a.) } \\
\hline & & $\overline{M_{3}(G P I)}$ & $M_{1}($ RVD) & $\mathrm{M}_{2}(\mathrm{GPA})$ \\
\hline (1) APE & $\begin{array}{l}9.44(8.8-9.9) \\
(100)\end{array}$ & $\begin{array}{l}7.58(7.5-7.6) \\
(1.00)\end{array}$ & $\begin{array}{l}7.74(7.5-7.9) \\
(1.00)\end{array}$ & $\begin{array}{l}8.19(8.1-8.3) \\
(1.00)\end{array}$ \\
\hline (2) MeFur & $\begin{array}{l}8.65(7.7-9.6) \\
(80 \pm 12)\end{array}$ & $\begin{array}{l}7.62(7.5-7.7) \\
(1.00)\end{array}$ & $\begin{array}{l}6.89(6.7-7.1) \\
(1.00)\end{array}$ & $\begin{array}{l}6.46(6.4-6.5) \\
(1.00)\end{array}$ \\
\hline (3) Methacholine & $\begin{array}{l}8.60(7.1-9.9) \\
(64 \pm 6)\end{array}$ & $\begin{array}{l}7.51(7.2-7.8) \\
(1.00)\end{array}$ & $\begin{array}{l}6.51(6.2-6.8) \\
(1.00)\end{array}$ & $\begin{array}{l}7.08(7.0-7.2) \\
(1.00)\end{array}$ \\
\hline (4) Oxotremorine & $\begin{array}{l}8.56(7.7-9.4) \\
(95 \pm 5)\end{array}$ & $\begin{array}{l}7.39(7.1-7.7) \\
(1.00)\end{array}$ & $\begin{array}{l}7.77(7.7-7.9) \\
(1.00)\end{array}$ & $\begin{array}{l}7.65(7.6-7.8) \\
(1.00)\end{array}$ \\
\hline (5) Carbacbol & $\begin{array}{l}8.55(7.5-9.6) \\
(80 \pm 14)\end{array}$ & $\begin{array}{l}6.67(6.6-6.7) \\
(1.00)\end{array}$ & $\begin{array}{l}6.77(6.7-6.9) \\
(1.00)\end{array}$ & $\begin{array}{l}6.90(6.8-7.0) \\
(1.00)\end{array}$ \\
\hline (6) GPE & $\begin{array}{l}8.25(7.2-9.3) \\
(83 \pm 15)\end{array}$ & $\begin{array}{l}7.13(6.9-7.3) \\
(1.00)\end{array}$ & $\begin{array}{l}7.28(7.1-7.4) \\
(1.00)\end{array}$ & $\begin{array}{l}6.97(6.8-7.1) \\
(1.00)\end{array}$ \\
\hline (7) (S)-Aceclidine & $\begin{array}{l}8.15(7.3-9.0) \\
(96 \pm 8)\end{array}$ & $\begin{array}{l}6.52(6.4-6.6) \\
(1.00)\end{array}$ & $\begin{array}{l}6.60(6.5-6.7) \\
(1.00)\end{array}$ & $\begin{array}{l}6.48(6.4-6.6) \\
(1.00)\end{array}$ \\
\hline (8) Arecoline & $\begin{array}{l}7.77(6.9-8.7) \\
(77 \pm 7)\end{array}$ & $\begin{array}{l}6.46(6.3-6.6) \\
(1.00)\end{array}$ & $\begin{array}{l}6.69(6.6-6.8) \\
(1.00)\end{array}$ & $\begin{array}{l}6.84(6.8-6.9) \\
(1.00)\end{array}$ \\
\hline (9) bis- $\mathrm{ABE}$ & $\begin{array}{l}7.70(7.0-8.4) \\
(79 \pm 6)\end{array}$ & $\begin{array}{l}6.27(6.1-6.4) \\
(0.89 \pm 0.09)\end{array}$ & $\begin{array}{l}6.94(6.8-7.1) \\
(1.00)\end{array}$ & $\begin{array}{l}7.10(7.0-7.2) \\
(1.00)\end{array}$ \\
\hline (10) Guvacoline & $\begin{array}{l}7.58(6.4-8.7) \\
(69 \pm 6)\end{array}$ & $\begin{array}{l}6.43(6.1-6.7) \\
(1.00)\end{array}$ & $\begin{array}{l}5.95(5.9-6.0) \\
(1.00)\end{array}$ & $\begin{array}{l}6.61(6.5-6.7) \\
(1.00)\end{array}$ \\
\hline (11) 4-Cl-McN-A-343 & $\begin{array}{l}6.82(6.2-7.4) \\
(63 \pm 10)\end{array}$ & $\begin{array}{l}5.35(5.2-5.5) \\
(1.00)\end{array}$ & $\begin{array}{l}7.06(7.0-7.1) \\
(1.00)\end{array}$ & $\begin{array}{l}5.26(5.1-5.4) \\
(0.77 \pm 0.12)\end{array}$ \\
\hline (12) (R)-NAEE & $\begin{array}{l}6.70(6.5-6.9) \\
(92 \pm 2)\end{array}$ & $\begin{array}{l}5.78(5.7-5.9) \\
(1.00)\end{array}$ & $\begin{array}{l}\text { inactive } \\
\left(\mathrm{pA}_{2}=5.34\right)\end{array}$ & $\begin{array}{l}5.82(5.7-5.9) \\
(0.87 \pm 0.13)\end{array}$ \\
\hline (13) NEN-APE & $\begin{array}{l}6.60(6.2-7.0) \\
(71 \pm 12)\end{array}$ & $\begin{array}{l}4.65(4.4-4.9) \\
(0.46 \pm 0.08)\end{array}$ & $\begin{array}{l}\text { inactive } \\
\left(\mathrm{pA}_{2}=5.81\right)\end{array}$ & $\begin{array}{l}6.48(6.4-6.6) \\
(0.76 \pm 0.05)\end{array}$ \\
\hline (14)(R)-Aceclidine & $\begin{array}{l}6.47(6.2-6.7) \\
(65 \pm 2)\end{array}$ & $\begin{array}{l}5.29(5.2-5.4) \\
(0.84 \pm 0.17)\end{array}$ & $\begin{array}{l}5.07(5.0-5.2) \\
(0.86 \pm 0.17)\end{array}$ & $\begin{array}{l}5.50(5.4-5.6) \\
(1.00)\end{array}$ \\
\hline (15) (S)-NAEE & $\begin{array}{l}6.46(6.1-6.9) \\
(73 \pm 8)\end{array}$ & $\begin{array}{l}5.19(5.1-5.3) \\
(0.93 \pm 0.04)\end{array}$ & $\begin{array}{l}\text { inactive } \\
\left(\mathrm{pA}_{2}=4.75\right)\end{array}$ & $\begin{array}{l}4.77(4.7-4.8) \\
(0.58 \pm 0.13)\end{array}$ \\
\hline (16) $\mathrm{McN}-\mathrm{A}-343$ & $\begin{array}{l}6.19(5.6-6.7) \\
(51 \pm 12)\end{array}$ & $\begin{array}{l}4.96(4.8-5.1) \\
(0.51 \pm 0.07)\end{array}$ & $\begin{array}{l}6.57(6.5-6.7) \\
(1.00)\end{array}$ & $\begin{array}{l}4.87(4.5-5.3) \\
(0.49 \pm 0.10)\end{array}$ \\
\hline
\end{tabular}


3.1.2. Effect of muscarinic agonists on kidneys preconstricted by cirazoline

During vasoconstriction induced by cirazoline $\left(10^{-7}\right.$ $M)$, which evoked a stable and reproducible decrease in renal flow of $72 \pm 11 \%$ (mean \pm S.D., $n=51$; resulting perfusion flow between 2.9 and $6.7 \mathrm{ml} / \mathrm{min}$ ), injections of increasing doses of e.g. APE $\left(10^{-12}-3 \times 10^{-7}\right.$ mol), MeFur $\left(10^{-11}-2 \times 10^{-7} \mathrm{~mol}\right)$, bis-ABE $\left(10^{-10}\right.$ $\left.3 \times 10^{-7} \mathrm{~mol}\right)$ and $4-\mathrm{Cl}-\mathrm{McN}-\mathrm{A}-343\left(10^{-9}-3 \times 10^{-7}\right.$ mol) caused a dose-dependent and reversible dilation in the rat kidney (fig. 1). Related to the maximal vasodilation by $3 \times 10^{-7} \mathrm{~mol}$ APE (defined as $100 \%$ ), which itself reversed the cirazoline-induced flow reduction by $67 \pm 17 \%$ (mean \pm S.D., $n=51$ ), high doses of the other agents only partially reached this value, i.e. those producing more than $80 \%$ vasodilation were oxotremorine, (S)-aceclidine, (R)-NAEE, MeFur, GPE, bis-ABE and carbachol, those not reaching $80 \%$ were (S)-NAEE, arecoline, guvacoline, methacholine, 4-ClMcN-A-343, NEN-APE and McN-A-343. The ED 50 values of the agonists are listed in table 1.

The dose-response curves of the potent agonists, e.g. APE, MeFur and carbachol, to evoke vasodilation were more shallow than those obtained for the weaker

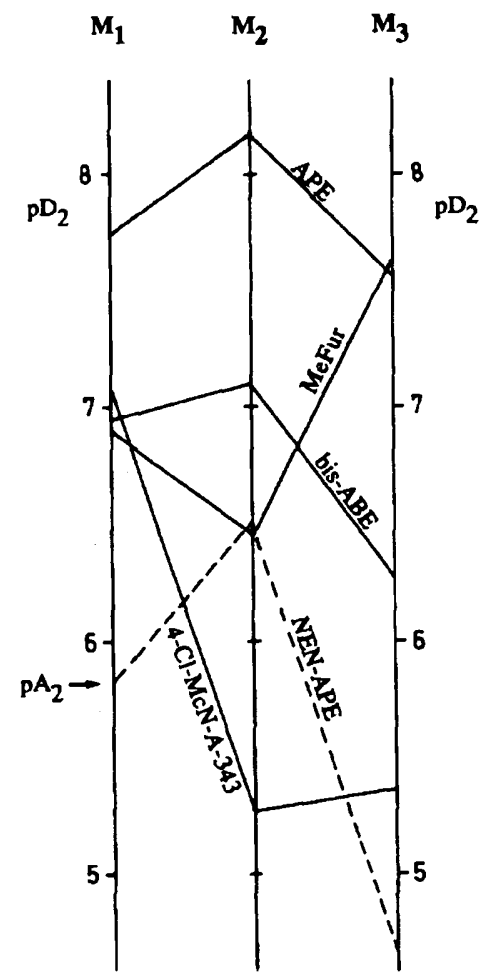

Fig. 3. Diagrammatic comparison of the potency $\left(\mathrm{pD}_{2}\right.$ values) of subtype-preferring muscarinic agonists to inhibit twitch contractions in rabbit vas deferens $\left(M_{1}\right.$ receptor), to elicit negative inotropy in guinea-pig left atrium $\left(M_{2}\right.$ receptor) and to evoke contraction in guinea-pig ileum longitudinal smooth muscle ( $M_{3}$ receptor). NENAPE was inactive as agonist at $M_{1}$ receptors, but behaved as a competitive antagonist $\left(\mathrm{pA}_{2}=5.81\right)$. agonists, e.g. 4-Cl-McN-A-343, (R)-NAEE and NENAPE. One possible explanation could be that steady state conditions after injection of the lower doses of the agonists are less closely attained than at higher doses during perfusion flow. Additionally, it must be kept in mind that muscarinic agonist-induced vasodilation per se might promote agonist removal from the kidney during increased perfusion flow.

\subsubsection{Effect of CHAPS}

Administration of CHAPS-containing $(0.2 \mathrm{mg} / \mathrm{ml})$ Tyrode solution for 5 min reduced basal perfusion flow from $18.6 \pm 0.4 \mathrm{ml} / \mathrm{min}$ to $15.4 \pm 0.7 \mathrm{ml} / \mathrm{min}$ (mean \pm S.D., $n=6$ ). No vasoconstrictor or vasodilator effect of bolus injections of APE, MeFur, 4-Cl-McN-A-343 and methacholine (up to $3 \times 10^{-7} \mathrm{~mol}$ ) was observed after perfusion of the kidney with CHAPS. The reduction in perfusion flow in response to continuous cirazoline administration $\left(10^{-7} \mathrm{M}\right)$ was slightly enhanced from $5.2 \pm 2.2$ (control) to $4.4 \pm 1.2 \mathrm{ml} / \mathrm{min}$ following CHAPS administration (means \pm S.D., $n=6$ ). In kidneys so treated, APE, MeFur, 4-Cl-McN-A-343 and methacholine (up to $3 \times 10^{-7}$ mol) did not evoke vasodilation by more than $5 \%$ of the values observed for the agonists in CHAPS-untreated organs and no vasoconstrictor response to these muscarinic agonists was seen. In contrast, the vasodilator response to nitroprusside $\left(10^{-7} \mathrm{~mol}\right)$ remained unchanged by CHAPS treatment (increase in perfusion flow by approximately $75 \%$ prior to and after CHAPS administration).

\subsubsection{Effect of muscarinic antagonists}

The antagonists did not significantly alter the vasoconstriction due to cirazoline $\left(10^{-7} \mathrm{M}\right)$, but attenuated the vasodilation due to APE $\left(5 \times 10^{-9} \mathrm{~mol}\right)$. Concentration-response curves of the antagonists are shown in fig. 2. In most cases, high concentrations of the antagonists abolished the effect of APE by more than $80 \%$. The $-\log \mathrm{EC}_{50}(\mathrm{M})$ values for the antagonists are summarized in table 2 .

The concentration-response curves for UH-AH 37, telenzepine, p-F-HHSiD and (S)-HHD were steeper than those for the other antagonists investigated. Assuming that a steady equilibrium was reached for all antagonists during the 20 -min perfusion period, the steep concentration-response curves of UH-AH 37, telenzepine, p-F-HHSiD and (S)-HHD might be explained by their weak displacement from muscarinic receptors due to bolus injection of the agonist APE because of slow off-kinetics.

\subsection{Guinea-pig ileum submucosal arterioles}

MeFur and bis-ABE, applied in a cumulative fashion to guinea-pig ileum submucosal arteriolar preparations produced concentration-dependent dilation of the 
(-)-noradrenaline-preconstricted vessel $\left(10^{-5} \mathrm{M}\right)$. These responses were resistant to blockade by tetrodotoxin $\left(10^{-6} \mathrm{M}\right)$ and hexamethonium $\left(10^{-4} \mathrm{M}\right)$, thereby confirming the direct activation of muscarinic receptors on the submucosal arteriole. Both agonists produced a maximal vasodilation of $85 \pm 4 \%$ (MeFur; $\mathrm{n}=6$; mean \pm S.E.M.) and $86 \pm 3 \%$ (bis-ABE; $n=5$; mean \pm S.E.M.), respectively, with $\mathrm{EC}_{50}$ values $\left( \pm\right.$ S.E.M.) of $0.24 \pm 0.07 \times 10^{-6} \mathrm{M}(\mathrm{n}=6)$ and $1.59 \pm$ $0.29 \times 10^{-6} \mathrm{M}(\mathrm{n}=5)$.

\subsection{Potency of agonists at muscarinic $M_{1}, M_{2}$ and $M_{3}$ receptors}

All agonist responses were characterized as muscarinic in nature in that their activities were blocked by pirenzepine $\left(10^{-7} \mathrm{M}\right)$ in rabbit vas deferens, AQ-RA $741\left(3 \times 10^{-7} \mathrm{M}\right)$ in guinea-pig atrium and p-F-HHSiD $\left(5 \times 10^{-7} \mathrm{M}\right)$ in guinea-pig ileum. Tetrodotoxin $\left(10^{-6}\right.$ $\mathrm{M})$ and hexamethonium $\left(10^{-4} \mathrm{M}\right)$ did not block agonist activities in guinea-pig atrium and ileum.

When close prostatic segments of the rabbit vas deferens were used, electrical field stimulation elicited phasic contractions of the 'rapid twitch' type, which could be inhibited concentration dependently by muscarinic agonists, e.g. APE, MeFur, bis-ABE, McN-A343, 4-Cl-McN-A-343, oxotremorine, carbachol, (S)and (R)-aceclidine (not shown), acting at inhibitory prejunctional $M_{1}$ receptors (Eltze, 1988). Except for the partial agonist, (R)-aceclidine (i.a. $=0.86$ ), all other compounds behaved as full agonists. In contrast, NENAPE, (R)- and (S)-NAEE were inactive at $M_{1}$ receptors in rabbit vas deferens and behaved as competitive antagonists. The potencies $\left(\mathrm{pD}_{2}\right.$ values) and apparent efficacies (i.a. values) obtained for the agonists at $M_{1}$ receptors are listed in table 1.

\section{TABLE 2}

Potency of muscarinic antagonists $\left(-\log \mathrm{EC}_{50}\right.$ ) to attenuate vasodilation due to bolus injections of $5 \times 10^{-9}$ mol APE in rat kidney preconstricted by $10^{-7} \mathrm{M}$ cirazoline, as well as affinity constants ( $\mathrm{pA}_{2}$ values) from constrained Schild plots for antagonism at muscarinic $\mathrm{M}_{3}$ receptors in guinea-pig ileum (GPI) and at $M_{1}$ and $M_{2}$ receptors in rabbit vas deferens (RVD).

The results are presented as means \pm S.E.M. of $n=5-6$ for rat kidney and $n=12-16$ experiments for $p A_{2}$ determination in guinea-pig ileum and rabbit vas deferens. $y=$ slope of Schild plot.

\begin{tabular}{|c|c|c|c|c|}
\hline \multirow[t]{2}{*}{ Drug } & \multirow{2}{*}{$\begin{array}{l}\text { Rat kidney } \\
-\log E C_{50}(M)\end{array}$} & \multicolumn{3}{|l|}{$\mathbf{p A}_{2}$} \\
\hline & & $\overline{M_{3}(G P I)}$ & $M_{1}(\mathrm{RVD})$ & $M_{2}(R V D)$ \\
\hline (1) Atropine & $8.42 \pm 0.08$ & $\begin{array}{l}8.99 \pm 0.07 \\
y=1.09 \pm 0.07\end{array}$ & $\begin{array}{l}9.53 \pm 0.06 \\
y=1.13 \pm 0.11\end{array}$ & $\begin{array}{l}9.05 \pm 0.11^{a} \\
y=1.68 \pm 0.02^{b}\end{array}$ \\
\hline (2) 4-DAMP & $8.30 \pm 0.09$ & $\begin{array}{l}8.83 \pm 0.17^{c} \\
y=1.01 \pm 0.03\end{array}$ & $\begin{array}{l}9.12 \pm 0.08^{a} \\
y=1.14 \pm 0.02\end{array}$ & $\begin{array}{l}8.16 \pm 0.10 \\
y=1.08 \pm 0.02\end{array}$ \\
\hline (3) (R)-HHD & $7.51 \pm 0.06$ & $\begin{array}{l}8.35 \pm 0.04{ }^{d} \\
y=0.92 \pm 0.07\end{array}$ & $\begin{array}{l}8.71 \pm 0.05^{d} \\
y=1.26 \pm 0.09^{b}\end{array}$ & $\begin{array}{l}6.83 \pm 0.07 \\
y=1.15 \pm 0.19\end{array}$ \\
\hline (4) HHSiD & $7.26 \pm 0.08$ & $\begin{array}{l}7.76 \pm 0.06 \\
y=1.06 \pm 0.07\end{array}$ & $\begin{array}{l}7.92 \pm 0.07^{2} \\
y=1.09 \pm 0.03\end{array}$ & $\begin{array}{l}6.54 \pm 0.07 \\
y=0.86 \pm 0.07\end{array}$ \\
\hline (5) UH-AH 37 & $6.96 \pm 0.05$ & $\begin{array}{l}8.07 \pm 0.08^{e} \\
y=1.16 \pm 0.13\end{array}$ & $\begin{array}{l}8.64 \pm 0.08^{e} \\
y=1.04 \pm 0.08\end{array}$ & $\begin{array}{l}7.15 \pm 0.12^{c} \\
y=1.22 \pm 0.10^{b}\end{array}$ \\
\hline (6) Telenzepine & $6.90 \pm 0.04$ & $\begin{array}{l}7.87 \pm 0.08 \\
y=1.07 \pm 0.05\end{array}$ & $\begin{array}{l}8.86 \pm 0.06^{\circ} \\
y=1.49 \pm 0.05^{b}\end{array}$ & $\begin{array}{l}7.51 \pm 0.09^{a} \\
y=1.19 \pm 0.04^{b}\end{array}$ \\
\hline (7) Mequitamium & $6.72 \pm 0.11$ & $\begin{array}{l}8.14 \pm 0.04 \\
y=1.01 \pm 0.07\end{array}$ & $\begin{array}{l}8.68 \pm 0.08 \\
y=1.04 \pm 0.24\end{array}$ & $\begin{array}{l}8.36 \pm 0.06 \\
y=1.25 \pm 0.08 b\end{array}$ \\
\hline (8) Pirenzepine & $6.19 \pm 0.09$ & $\begin{array}{l}6.87 \pm 0.20^{c} \\
y=0.89 \pm 0.11\end{array}$ & $\begin{array}{l}8.08 \pm 0.04 \\
y=1.14 \pm 0.06\end{array}$ & $\begin{array}{l}6.23 \pm 0.08 \\
y=1.07 \pm 0.04\end{array}$ \\
\hline (9) Nuvenzepine & $6.12 \pm 0.07$ & $\begin{array}{l}7.03 \pm 0.09^{e} \\
y=1.05 \pm 0.13\end{array}$ & $\begin{array}{l}7.74 \pm 0.08^{e} \\
y=1.07 \pm 0.13\end{array}$ & $\begin{array}{l}6.63 \pm 0.10^{c} \\
y=1.02 \pm 0.03\end{array}$ \\
\hline (10) p-F-HHSiD & $6.00 \pm 0.07$ & $\begin{array}{l}7.49 \pm 0.09^{c} \\
y=1.01 \pm 0.24\end{array}$ & $\begin{array}{l}6.77 \pm 0.07^{e} \\
y=1.11 \pm 0.12\end{array}$ & $\begin{array}{l}6.09 \pm 0.11^{c} \\
y=1.09 \pm 0.21\end{array}$ \\
\hline (11) Himbacine & $5.89 \pm 0.05$ & $\begin{array}{l}7.10 \pm 0.09 \\
y=0.98 \pm 0.09\end{array}$ & $\begin{array}{l}8.05 \pm 0.10^{2} \\
y=1.16 \pm 0.03\end{array}$ & $\begin{array}{l}8.06 \pm 0.09 \\
y=1.00 \pm 0.08\end{array}$ \\
\hline (12) Idaverine & $5.72 \pm 0.11$ & $\begin{array}{l}7.77 \pm 0.04 \\
y=1.01 \pm 0.08\end{array}$ & $\begin{array}{l}9.02 \pm 0.11 \\
y=1.34 \pm 0.09^{b}\end{array}$ & $\begin{array}{l}8.72 \pm 0.05 \\
y=1.12 \pm 0.08\end{array}$ \\
\hline (13) AF-DX 384 & $5.72 \pm 0.09$ & $\begin{array}{l}7.41 \pm 0.07 \\
y=0.98 \pm 0.04\end{array}$ & $\begin{array}{l}8.61 \pm 0.09 \\
y=1.23 \pm 0.11^{b}\end{array}$ & $\begin{array}{l}8.58 \pm 0.10 \\
y=1.42 \pm 0.09 b\end{array}$ \\
\hline (14) AQ-RA 741 & $5.40 \pm 0.10$ & $\begin{array}{l}6.97 \pm 0.07 \\
y=0.87 \pm 0.13\end{array}$ & $\begin{array}{l}8.44 \pm 0.06 \\
y=1.20 \pm 0.16\end{array}$ & $\begin{array}{l}8.62 \pm 0.09 \\
y=1.69 \pm 0.17^{b}\end{array}$ \\
\hline (15) (S)-HHD & $4.64 \pm 0.11$ & $\begin{array}{l}6.07 \pm 0.05^{d} \\
y=0.87 \pm 0.17\end{array}$ & $\begin{array}{l}5.97 \pm 0.04 \\
y=0.87 \pm 0.10\end{array}$ & $\begin{array}{l}5.25 \pm 0.04 \\
y=0.96 \pm 0.13\end{array}$ \\
\hline
\end{tabular}

a Data taken from Eltze (1988). ${ }^{\mathrm{b}}$ Slope significantly different from unity $(\mathrm{P}<0.05) .{ }^{\mathrm{c}}$ Data taken from Eltze and Figala $(1988) .{ }^{d}$ Data taken from Feifel et al. (1990). ${ }^{\circ}$ Data taken from Eltze et al. (1992). 
Similarly, the agonists caused negative inotropy due to stimulation of muscarinic $\mathbf{M}_{2}$ receptors in left atrium, and smooth muscle contraction due to stimulation of $\mathrm{M}_{3}$ receptors in ileum of the guinea-pig. Potencies ( $\mathrm{pD}_{2}$ values) and apparent efficacies (i.a. values) of the agonists at cardiac $\mathrm{M}_{2}$ and smooth muscle $\mathrm{M}_{3}$ receptors are also listed in table 1.

Comparison of data obtained at different muscarinic receptor subtypes (table 1 ) shows that most compounds did not discriminate between $\mathbf{M}_{1}, \mathbf{M}_{2}$ and $\mathbf{M}_{3}$ recep-
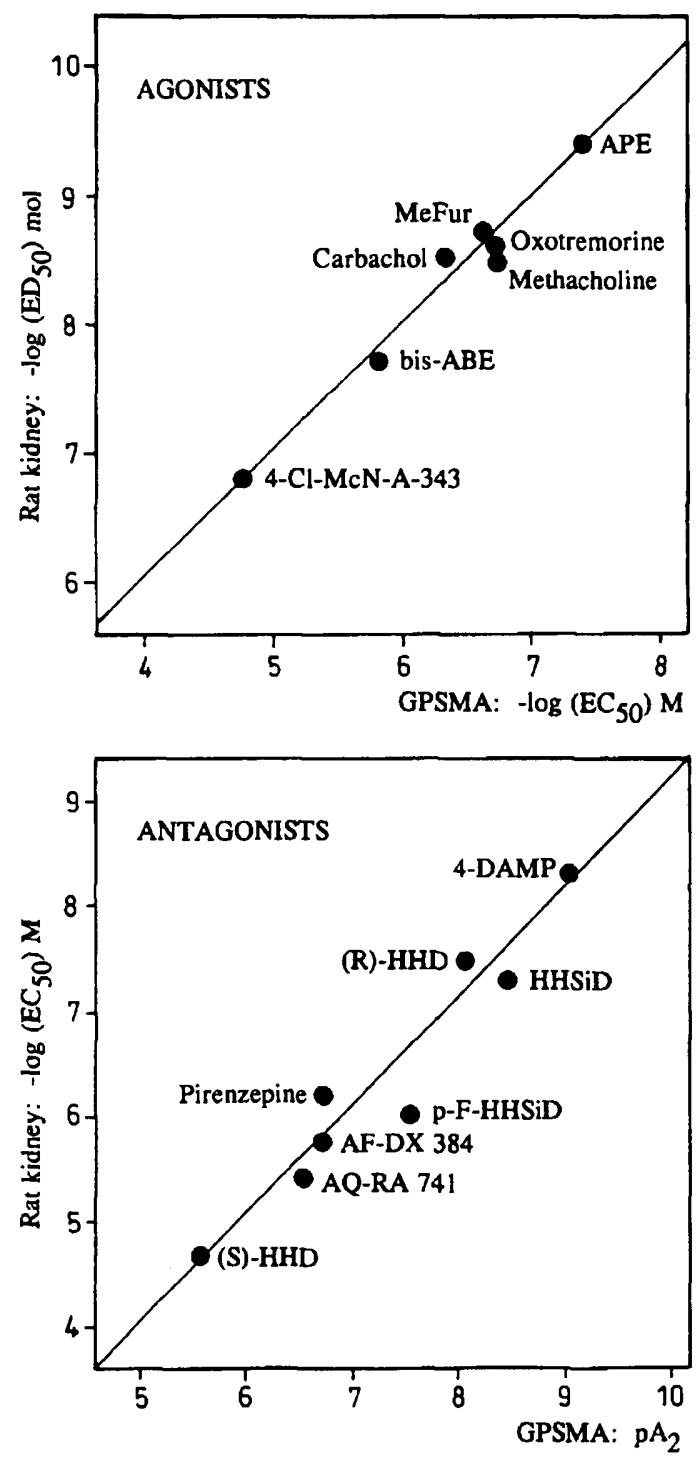

Fig. 4. Top: Relationship between the potencies of muscarinic agonists to evoke vasodilation in rat kidney (table 1$)$ and to relax (-)noradrenaline-preconstricted guinea-pig submucosal arterioles (GPSMA). Bottom: relationship between the potency of muscarinic antagonists to attenuate APE-induced vasodilation in rat kidney (table 2) and their functional affinities ( $\mathrm{pA}_{2}$ values) for $\mathrm{M}_{3}$ receptors in GPSMA. All antagonist and most of the agonist data (except for MeFur and bis-ABE, this study) obtained in GPSMA were taken from Bungardt et al. (1992).
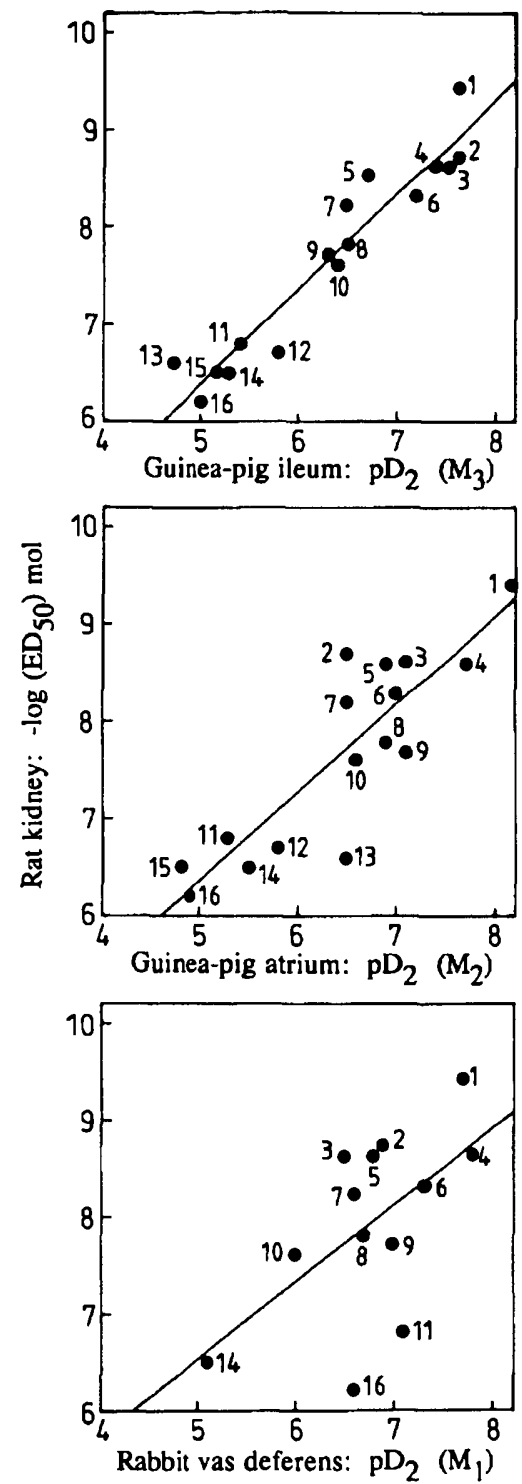

Fig. 5. Relationships between the potencies of muscarinic agonists to evoke vasodilation in rat kidney and (top) to stimulate $M_{3}$ receptors in guinea-pig ileum, (middle) $\mathbf{M}_{2}$ receptors in guinea-pig atrium, as well as (bottom) $M_{1}$ receptors in rabbit vas deferens, respectively. Numbering of drugs refers to table 1.

tors. However, APE was the most potent agonist, possessing a small preference for $\mathbf{M}_{2}$ receptors (Lambrecht et al., 1993). The bivalent ligand, bis-ABE (Moser et al., 1990), exhibited high potency at $M_{1}$ and $M_{2}$ and a 5- and 6-fold lower potency at $\mathbf{M}_{3}$ receptors, respectively $\left(M_{2}=M_{1}>M_{3}\right)$. A different potency rank order was found for MeFur $\left(M_{3}>M_{1} \geqslant M_{2}\right)$, methacholine $\left(M_{3}>M_{2}>M_{1}\right)$ as well as McN-A-343 and its 4-chloro derivative $\left(M_{1} \gg M_{2}=M_{3}\right)$ (Lambrecht et al., 1993). The (R)- and (S)-enantiomers of NAEE (Zorn et al., 1987) were non-selective agonists at $M_{2}$ and $M_{3}$ receptors (eudismic ratios $=11.2$ and 3.9 , respectively), but competitive antagonists at $\mathbf{M}_{1}$ receptors (eudismic ratio 
= 3.9). NEN-APE was a potent partial agonist at $\mathrm{M}_{2}$ receptors $\left(\mathrm{pD}_{2}=6.48\right)$ but about 100 -fold less potent at ileal $\mathrm{M}_{3}$ receptors $\left(\mathrm{pD}_{2}=4.65\right)$, and behaved as a competitive antagonist at $\mathrm{M}_{1}$ receptors $\left(\mathrm{pA}_{2}=5.81\right)$ (Wolf-Pflugmann et al., 1989). Fig. 3 summarizes graphically the results obtained with these subtype-preferring muscarinic agonists.

\subsection{Affinity of antagonists at muscarinic $M_{1}, M_{2}$ and $M_{3}$ receptors}

Neurogenic contractions of the rabbit isolated vas deferens to field stimulation could be inhibited concentration dependently by the $\mathrm{M}_{1}$-selective agonist, $\mathrm{McN}$ A-343 $\left(10^{-7}-2 \times 10^{-6} \mathrm{M}\right)$ (Lambrecht et al., 1993), or potentiated by carbachol $\left(10^{-8}-2 \times 10^{-7} \mathrm{M}\right)$ (Eltze, 1988). Both effects were antagonized in a surmountable fashion by the muscarinic antagonists tested in the present study, and the $\mathrm{pA}_{2}$ values of the compounds at inhibitory prejunctional $\mathbf{M}_{1}$ and excitatory postjunctional $\mathbf{M}_{2}$ receptors (Eltze, 1988) are listed in table 2. Among the antagonists investigated, 4-DAMP, pirenzepine, telenzepine, UH-AH 37, HHSiD, (R)-HHD and nuvenzepine clearly showed a preference (factor $\geqslant$ 10) for $M_{1}$ receptors, whereas atropine, himbacine, mequitamium, p-F-HHSiD, AQ-RA 741, AF-DX 384 and (S)-HHD antagonized $M_{1}$ and $M_{2}$ receptor-mediated responses with similar potency (factor $<5$; table 2). The affinity of idaverine appeared to be equally high for $M_{1}$ and $M_{2}$ receptors in rabbit vas deferens. All antagonists inhibited the contractions of the guinea-pig ileum evoked by acetylcholine or APE. There was a concentration-dependent parallel shift to the right of the agonist concentration-response curves without either basal tension or maximum responses being affected. The antagonists showed quite wide variations in their antimuscarinic potencies at smooth muscle $M_{3}$ receptors, their $\mathrm{pA}_{2}$ values differing by up to three orders of magnitude (table 2).

In all cases, the Schild plots were linear and most slopes of the regression lines were not significantly different from unity $(P>0.05)$ (table 2$)$, indicating simple competitive antagonism at the three muscarinic receptor subtypes.

\subsection{Linear regressions}

In the first instance, we compared the potency of a number of agonists and antagonists at muscarinic receptors in rat kidney with their effects in resistance vessels of the submucosal arterioles of the guinea-pig small intestine. In the latter preparation, only functional muscarinic $M_{3}$ receptors have been demonstrated, the activation of which causes vasodilation (Bungardt et al., 1992). An excellent correlation re- sulted $(\mathrm{r}=0.988, \mathrm{P}<0.001 ; \beta=0.98$ not significantly different from unity, $P>0.05$ ) on comparison of the potencies of seven agonists (APE $>$ methacholine $=$ oxotremorine $=$ MeFur $=$ carbachol $>$ bis-ABE $>4-\mathrm{Cl}-$ McN-A-343) to evoke vasodilation in both vascular preparations (fig. 4, top). There was also a highly significant correlation $(\mathrm{r}=0.9498, \mathrm{P}<0.001 ; \beta=1.00$ not significantly different from unity, $P>0.05$ ) when the potencies of eight antagonists to inhibit APE-induced vasodilation in rat kidney were compared with
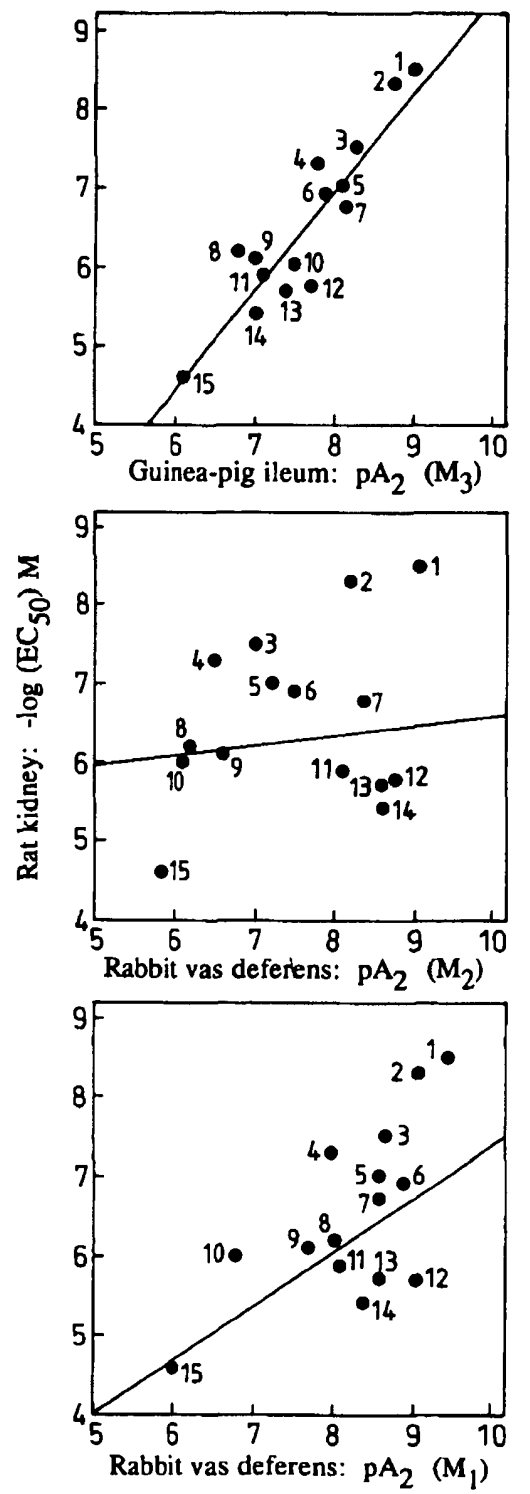

Fig. 6. Relationships between the potencies of muscarinic antagonists to attenuate APE-induced vasodilation in rat kidney and (top) their affinities for muscarinic $\mathbf{M}_{3}$ receptors in guinea-pig ileum, (middle) $\mathbf{M}_{2}$ receptors in rabbit vas deferens, as well as (bottom) their affinities for muscarinic $M_{1}$ receptors in rabbit vas deferens, respectively. Numbering of drugs refers to table 2 . 
their $\mathrm{pA}_{2}$ values for $\mathbf{M}_{3}$ receptor antagonism in guinea-pig submucosal arterioles (fig. 4, bottom).

Comparing the potencies of muscarinic agonists to attenuate cirazoline-induced renal vasoconstriction with the potencies from contraction studies with muscarinic $M_{3}$ receptors in guinea-pig ileum (table 1), a highly significant correlation resulted (fig. 5 , top; $r=$ $0.95, \mathrm{P}<0.001 ; \beta=0.95$ not significantly different from unity, $P>0.001$ ). Weak correlations were obtained when comparing agonist potencies in rat kidney with the respective $\mathrm{pD}_{2}$ values from experiments on $\mathrm{M}_{2}$ receptors in guinea-pig atrium (fig. 5, middle; $r=0.87$, $\mathrm{P}<0.001 ; \beta=0.90$ not significantly different from unity, $P>0.05$ ) or on $M_{1}$ receptors in rabbit vas deferens (fig. 5 , bottom; $r=0.61, P<0.01 ; \beta=0.81$ significantly different from unity, $\mathrm{P}<0.01$ ).

A highly significant correlation also resulted from comparison of $-\log \mathrm{EC}_{50}$ values of the antagonists derived from the rat kidney experiments with their respective $\mathrm{pA}_{2}$ values at muscarinic $\mathrm{M}_{3}$ receptors in guinea-pig ileum (fig. 6, top; $\mathrm{r}=0.91, \mathrm{P}<0.001 ; \beta=$ 1.24 significantly different from unity, $P<0.05$ ). In contrast, no significant correlation was obtained between the $-\log \mathrm{EC}_{50}$ values of the antagonists from the rat kidney experiments and $\mathrm{pA}_{2}$ values of the antagonists at $\mathbf{M}_{2}$ receptors in rabbit vas deferens (fig. 6 , middle; $r=0.29, P>0.05 ; \beta=0.27$ significantly different from unity, $P<0.001)$. A weak correlation resulted when the antagonist potencies in rat kidney were compared with $M_{1}$ receptor affinities in rabbit vas deferens (fig. 6 , bottom; $r=0.66, P<0.01 ; \beta=0.76$ significantly different from unity, $\mathrm{P}<0.05$ ).

\section{Discussion}

\subsection{General considerations}

In the past, the existence of a cholinergic system within the kidney was the object of controversy (Di Bona, 1982). While there is now strong evidence for muscarinic receptors in the kidney (Garg, 1992), the potential source of acetylcholine in this organ is less clear. Specific binding of $\left[{ }^{3} \mathrm{H}\right] \mathrm{QNB}$ has been demonstrated in rat kidney membranes. The majority of these renal muscarinic binding sites were suggested to be primarily localized postsynaptically within the smooth muscle of the renal vascular tree and to a lesser extent within cortical and medullary tubules (Yamada et al., 1986). In addition, cholinergic markers such as acetylcholinesterase, choline acetyltransferase and a high-affinity choline uptake system, have been suggested to be present in mammalian kidney (Pirola et al., 1989). Recently, muscarinic $\mathrm{M}_{3}$ binding sites in rat kidney cortex have been identified, probably located in vascular tissue (Blankesteijn et al., 1993).
In vitro studies on the (-)-noradrenaline-preconstricted, constant-flow perfused rat kidney suggested that vasodilator muscarinic receptors mediate the endothelium-dependent decrease in perfusion pressure (Bhardwaj and Moore, 1988). The present study was therefore designed to further characterize this muscarinic receptor, using a series of subtype-preferring agonists and antagonists, including three pairs of enantiomers: (R)- and (S)-aceclidine (Lambrecht, 1976), -NAEE (Zorn et al., 1987) and -HHD (Feifel et al., 1990). The results obtained provide convincing evidence that a single functional muscarinic receptor, the $\mathrm{M}_{3}$ subtype, mediates muscarinic vasodilation in rat renal resistance vessels.

\subsection{Agonist studies}

Among the agonists investigated in the three tissues containing $\mathbf{M}_{1}$ (rabbit vas deferens), $\mathbf{M}_{2}$ (guinea-pig left atrium) and $M_{3}$ receptors (guinea-pig ileum), the functional subtype involved can be characterized by means of four agonists exhibiting different rank orders of potencies (fig. 3). $\mathrm{M}_{1}: 4-\mathrm{Cl}-\mathrm{McN}-\mathrm{A}-343=$ bis-ABE $=$ MeFur $\gg$ NEN-APE; $M_{2}$ : bis-ABE $>$ NEN-APE = MeFur $>4-\mathrm{Cl}-\mathrm{McN}-\mathrm{A}-343 ; \mathrm{M}_{3}$ : MeFur $>$ bis-ABE $>$ 4-Cl-McN-A-343 > NEN-APE.

The agonists tested in the present study, dose dependently increased perfusion flow in rat kidney previously preconstricted by the continuous presence of cirazoline. With the exception of McN-A-343, they produced maximal effects between 63 and 96\% (related to the maximal vasodilation elicited by APE; fig. 1). The rank order of potency was: APE $>$ MeFur $=$ methacholine $=$ oxotremorine $=$ carbachol $>$ GPE $>$ (S)-aceclidine $>$ arecoline $=$ bis-ABE $=$ guvacoline $>$ 4-Cl-McN-A-343 = (R)-NAEE = NEN-APE = (R)-aceclidine $=(\mathrm{S})-\mathrm{NAEE}>\mathrm{McN}-\mathrm{A}-343$. This is consistent with the potency profile of the agonists (a) in the guinea-pig submucosal arteriolar preparation (fig. 4), where only $M_{3}$ subtype vasodilator muscarinic receptors have been demonstrated (Bungardt et al., 1992), and (b) as observed in contraction experiments with the longitudinal smooth muscle preparation of the guinea-pig ileum (fig. 5), the functional muscarinic receptor of which has been characterized as the $\mathbf{M}_{3}$ subtype (Eglen et al., 1992). These results suggest that muscarinic $\mathbf{M}_{3}$ receptors mediate the vasodilation in rat kidney.

\subsection{Antagonist studies}

Besides some unselective antagonists, i.e. atropine, mequitamium (Renzetti et al., 1990; this study) and (S)-HHD (Feifel et al., 1990) which did not discriminate between muscarinic $\mathbf{M}_{1}, \mathbf{M}_{2}$ and $\mathbf{M}_{3}$ receptor subtypes, pirenzepine (Hulme et al., 1990), telenzepine 
(Eltze, 1988), UH-AH 37 (Doods and Mayer, 1989; Wess et al., 1991) and nuvenzepine (Eltze et al., 1992) clearly distinguished $M_{1}$ from $M_{3}$ and $M_{2}$ receptors $\left(M_{1}>M_{3} \geqslant M_{2}\right)$ (table 2). The antagonists, 4-DAMP (Hulme et al., 1990), (R)-HHD (Feifel et al., 1990) and HHSiD (Lambrecht et al., 1988), consistently showed higher affinity to both $M_{1}$ and $M_{3}$ receptors than to $M_{2}$ receptors $\left(M_{1}=M_{3}>M_{2}\right)$, whereas p-F-HHSiD (Lambrecht et al., 1988) clearly discriminated between all muscarinic receptor subtypes investigated $\left(M_{3}>M_{1}\right.$ $>M_{2}$ ) (table 2). In accordance with affinities determined for idaverine at different muscarinic receptor binding sites (Lucot et al., 1991), antimuscarinic potencies of this antagonist at both $M_{1}$ and $M_{2}$ receptors in rabbit vas deferens were similar and about 10 times higher than at ileal $\mathbf{M}_{3}$ receptors $\left(M_{1}=M_{2}>M_{3}\right)$. The putative cardioselective antagonists, himbacine (Gilani and Cobbin, 1986; Eltze, 1988), AF-DX 384 (Eberlein et al., 1989) and AQ-RA 741 (Doods et al., 1991), showed higher affinity to both $M_{2}$ and $M_{1}$ than to $M_{3}$ receptors $\left(M_{2}=M_{1}>M_{3}\right)$ (table 2). The failure of himbacine, AF-DX 384 and AQ-RA 741 to discriminate between functional responses at muscarinic $\mathbf{M}_{1}$ and $M_{2}$ receptors in rabbit vas deferens contrasts with reports on the ability of the antagonists to distinguish between these receptor types in binding studies (Lazareno and Roberts, 1989; Doods et al., 1991; Dörje et al., 1991b). However, although pharmacological (Eltze, 1988) and immunological techniques using subtype-specific antisera (Dörje et al., 1991a) have shown that rabbit vas deferens is endowed only with $M_{1}$ and $M_{2}$ receptors, the inability of these antagonists to discriminate $M_{1}$ from $M_{2}$ receptor-mediated responses in rabbit vas deferens remains unclear and deserves further investigation.

All antagonists concentration dependently and reversibly abolished the vasorelaxant response to bolus injection of APE in rat kidney. Their $-\log \mathrm{EC}_{50}$ values for half-maximal inhibition of the vasorelaxant effect of APE significantly correlated with their affinities $\left(\mathrm{pA}_{2}\right.$ values) obtained in functional experiments with two established muscarinic $M_{3}$ receptor systems, (a) the submucosal arteriolar preparation (fig. 4) (Bungardt et al., 1992), and (b) the ileal smooth muscle of the guinea-pig (fig. 6) (Eglen et al., 1992). In contrast, the profile of antagonist potencies (fig. 6) is not at all consistent with the presence of functional $M_{1}$ and $M_{2}$ receptors in rat kidney. In addition, calculation of the eudismic ratio for the two enantiomers of HHD in rat kidney (741) and comparison of this value with data obtained at $M_{1}$ (550), $M_{2}$ (38) and $M_{3}$ receptors (240) further excludes the $M_{2}$ subtype for mediating vasodilation in rat kidney. Thus it can be concluded also from the antagonist characteristics that the functional muscarinic receptor mediating vasodilation in rat perfused kidney is of the $M_{3}$ subtype.

\subsection{Possible localization and function of renovascular muscarinic receptors}

In the rat isolated perfused kidney, (-)-noradrenaline constricts both preglomerular and postglomerular vessels, but only constriction of the former is sensitive to the $\mathrm{Ca}^{2+}$ channel antagonist, nisoldipine (Loutzenhiser et al., 1984). The $\alpha_{1}$-adrenoceptor agonist, cirazoline, used in the present study has been shown to evoke pressor responses in the pithed rat which depend on both entry of extracellular $\mathrm{Ca}^{2+}$ and the release of $\mathrm{Ca}^{2+}$ from intracellular sources (Nichols and Ruffolo, 1986). Although it is reasonable to suggest that cirazoline may also exert renal microvascular actions at sites similar to (-)-noradrenaline, the localization of renovascular dilation produced by stimulation of $\mathbf{M}_{3}$ receptors cannot be deduced from our experiments. However, it has been shown previously by vessel diameter observations via television microscopy in the split hydronephrotic rat kidney preparation that acetylcholine produced significant dilation of all preglomerular vessels (arcuate and interlobular arteries and afferent arterioles) and postglomerular efferent arterioles, its effect being greater at afferent than at efferent arterioles near the glomerulus (Fleming et al., 1987). Such a dilator pattern in response to acetylcholine is consistent with reports that it substantially increases renal blood flow but has little or no effect, on glomerular filtration rate (Burton et al., 1990). A surprising observation was that hemoglobin inhibited the effect of acetylcholine only in the efferent, but not in the afferent arteriole. Hence, acetylcholine appears to release nitric oxide (NO) only in the efferent arteriole and a different relaxing factor in the afferent arteriole (Loutzenhiser et al., 1990).

In anaesthetized rats, endogenous or acetylcholinestimulated release of NO may play an important role in the local regulation of renal cortical blood flow (Walder et al., 1991). Infusion of acetylcholine into the renal artery of anaesthetized rats increased only cortical flow, while medullary interstitial infusion increased both cortical and papillary blood flow. Only papillary blood flow was selectively reduced by inhibition of NO synthesis, thus indicating a role in the control of papillary blood flow by local production of NO in the renal medulla. A selective reduction in papillary blood flow by $M_{3}$ receptor stimulation may therefore be associated with sodium and water retention (Mattson et al., 1992).

\subsection{Summary and conclusion}

In summary, the present study investigated the muscarinic receptors in resistance vessels of rat isolated perfused kidney. The muscarinic receptor which mediates endothelium-dependent vasodilation of the cirazo- 
line-preconstricted renal vasculature was characterized by determining the potencies of a series of subtypepreferring agonists and the affinities of various selective antagonists. The results provide convincing evidence that a single muscarinic receptor, the $M_{3}$ subtype, mediates muscarinic vasodilation in rat kidney, which disappears after destruction of the endothelium by means of detergent. In endothelium-denuded rat kidney, muscarinic agonists failed to evoke any vascular effect at all.

\section{Acknowledgements}

The authors gratefully acknowledge the skillful technical assistance of Mrs. H. König, Mrs. C. Bürkle, Mrs. A. Bott and Mrs. S. Conzelmann. The work was supported by the Fonds der Chemischen Industrie (G.L., E.M., R.T.) and the Deutsche Forschungsgemeinschaft (G.L., R.T.).

\section{References}

Arunlakshana, O. and H.O. Schild, 1959, Some quantitative uses of drug antagonists, Br. J. Pharmacol. 14, 48.

Bhardwaj, R. and P.K. Moore, 1988, Endothelium-derived relaxing factor and the effects of acetylcholine and histamine on resistance blood vessels, Br. J. Pharmacol. 95, 835.

Blankesteijn, W.M., H.L.M. Siero, J.F. Rodrigues de Miranda, Y.J.B. Van Megen and F.G.M. Russel, 1993, Characterization of muscarinic receptors in rat kidney, Eur. J. Pharmacol. (Mol. Pharmacol. Section) 244, 21

Bungardt, E., E. Vockert, R. Feifel, U. Moser, R. Tacke, E. Mutschler, G. Lambrecht and A. Surprenant, 1992, Characterization of muscarinic receptors mediating vasodilation in guinea-pig ileum submucosal arterioles by the use of computer-assisted videomicroscopy, Eur. J. Pharmacol. 213, 53.

Burton, G.A., S. MacNeil, A. de Jonge and J. Haylor, 1990, Cyclic GMP release and vasodilatation induced by EDRF and atrial natriuretic factor in the isolated perfused kidney of the rat, $\mathrm{Br}$. J. Pharmacol. 99, 364.

De Michele, M., F. Amenta and C. Cavallotti, 1989, Autoradiographic localization of muscarinic receptors within the rat kidney, Eur. J. Pharmacol. 169, 297.

Di Bona, G.F., 1982, The functions of renal nerves, Rev. Physiol. Biochem. Pharmacol. 94, 75.

Doods, H. and N. Mayer, 1989, UH-AH 37, an ileal-selective muscarinic antagonist that does not discriminate between $M_{2}$ and $M_{3}$ binding sites, Eur. J. Pharmacol. 161, 215.

Doods, H., M. Entzeroth and N. Mayer, 1991, Cardioselectivity of AQ-RA 741, a novel tricyclic antimuscarinic drug, Eur. J. Pharmacol. 192, 147.

Dörje, F., A.I. Levey and M.R. Brann, 1991a, Immunological detection of muscarinic receptor subtype proteins $(\mathrm{ml}-\mathrm{m5})$ in rabbit peripheral tissues, Mol. Pharmacol. 40, 459.

Dörje, F., J. Wess, G. Lambrecht, R. Tacke, E. Mutschler and M.R. Brann, 1991b, Antagonist binding profiles of five cloned human muscarinic receptor subtypes, J. Pharmacol. Exp. Ther. 256, 727.

Eberlein, W.G., W. Engel, G. Mihm, K. Rudolf, B. Wetzel, M Entzeroth, N. Mayer and H.N. Doods, 1989, Structure-activity relationships and pharmacological profile of selective tricyclic antimuscarinics, Trends Pharmacol. Sci. 10 (Suppl.), 50.
Eglen, R.M. and R.L. Whiting, 1990, Heterogeneity of vascular muscarinic receptors, J. Auton. Pharmacol. 10, 233.

Eglen, R.M., N. Adham and R.L. Whiting, 1992, Acute desensitization of muscarinic receptors in the isolated guinea-pig ileal longitudinal muscle, J. Auton. Pharmacol. 12, 137.

Eltze, $M ., 1988$, Muscarinic $M_{1}$ - and $M_{2}$-receptors mediating opposite effects on neuromuscular transmission in rabbit vas deferens, Eur. J. Pharmacol. 151, 205.

Eltze, M. and V. Figala, 1988, Affinity and selectivity of biperiden enantiomers for muscarinic receptor subtypes, Eur. J. Pharmacol. $158,11$.

Eltze, M., R. Boer, K.H. Sanders and N. Kolassa, 1991, Vasodilatation elicited by $5-\mathrm{HT}_{1 \mathrm{~A}}$ receptor agonists in constant-pressure perfused rat kidney is mediated by blockade of $\alpha_{1 \mathrm{~A}}$-adrenoceptors, Eur. J. Pharmacol. 202, 33.

Eltze, M., E. Mutschler and G. Lambrecht, 1992, Affinity profiles of pizotifen, ketotifen and other tricyclic antimuscarinics at muscarinic receptor subtypes $\mathbf{M}_{1}, \mathbf{M}_{2}$ and $\mathbf{M}_{3}$, Eur. J. Pharmacol. $211,283$.

Feifel, R., M. Wagner-Röder, C. Strohmann, R. Tacke, M. Waelbroeck, J. Christophe, E. Mutschler and G. Lambrecht, 1990. Stereoselective inhibition of muscarinic receptor subtypes by the enantiomers of hexahydro-difenidol and acetylenic analogues, $\mathrm{Br}$. J. Pharmacol. 99, 455.

Fleming, J.T., N. Parekh and M. Steinhausen, 1987, Calcium antagonists preferentially dilate preglomerular vessels of hydronephrotic kidney, Am. J. Physiol. 22, F1157.

Garg, L.C., 1992, Actions of adrenergic and cholinergic drugs on renal tubular cells, Pharmacol. Rev. 44, 81

Gilani, A.S.H. and L. Cobbin, 1986, The cardioselectivity of him bacine: a muscarinic receptor antagonist, Naunyn-Schmiedeb. Arch. Pharmacol. 332, 16.

Hulme, E.C., N.J.M. Birdsall and N.J. Buckley, 1990, Muscarinic receptor subtypes, Ann. Rev. Pharmacol. Toxicol. 30, 633.

Jaiswal, N., R.K. Jaiswal and K.U. Malik, 1991, Muscarinic receptor-mediated prostacyclin and cGMP synthesis in cultured vascular cells, Mol. Pharmacol. 40, 101.

Lambrecht, G., 1976, Struktur- und Konformations-Wirkungs-Beziehungen heterocyclischer Acetylcholinanaloga. I. Muskarinwirkung enantiomerer 3-Acetoxychinuclidine und 3-Acetoxypiperidine, Eur. J. Med. Chem. 11, 461.

Lambrecht, G., R. Feifel, B. Forth, C. Strohmann, R. Tacke and E. Mutschler, 1988, p-Fluoro-hexahydro-sila-difenidol: the first $\mathrm{M}_{2 \beta}$-selective muscarinic antagonist, Eur. J. Pharmacol. 152, 193.

Lambrecht, G., U. Moser, U. Grimm, O. Pfaff, U. Hermanni, C. Hildebrandt, M. Waelbroeck, J. Christophe and E. Mutschler, 1993, New functionally selective muscarinic agonists, Life Sci. 52, 481.

Lazareno, S. and F.F. Roberts, 1989, Functional and binding studies with muscarinic $\mathbf{M}_{2}$-subtype selective antagonists, $\mathrm{Br}$. J. Pharma col. $98,309$.

Lazareno, S., N.J. Buckley and F.F. Roberts, 1990, Characterization of muscarinic $\mathbf{M}_{4}$ binding sites in rabbit lung, chicken heart, and NG 108-15 cells, Mol. Pharmacol. 38, 805.

Loutzenhiser, R., M. Epstein, C. Horton and P. Sonke, 1984, Reversal of the calcium antagonists nisoldipine of norepinephrineinduced reduction in GFR: evidence for preferential antagonism of preglomerular vasoconstriction, J. Pharmacol. Exp. Ther. 232, 382.

Loutzenhiser, R., K. Hayashi and M. Epstein, 1990, Evidence for multiple endothelium-derived relaxing factors (EDRFs) in the renal microcirculation: hemoglobin inhibits actylcholine $(\mathrm{ACH})$ induced vasodilation of efferent, but not afferent arterioles, Kidney Int. 37, 373.

Lucot, J.B., K.J. Van Charldorp and M.T.M. Tulp, 1991, Idaverine, an $\mathbf{M}_{2}$-vs. $\mathbf{M}_{3}$-selective muscarinic antagonist, does not preven motion sickness in cats, Pharmacol. Biochem. Behav. 40, 345. 
Mattson, D.L., R.J. Roman and A.W. Cowley, 1992, Role of nitric oxide in renal papillary blood flow and sodium excretion, Hypertension 19, 766.

Moser, U., M. Galvan, A. Immel-Sehr, E. Mutschler and G. Lambrecht, 1990, Muscarinic activity of arecaidine bjvalent ligands with conformationally restricted spacers, Eur. J. Pharmacol. 183, 1991.

Nichols, A.J. and R.R. Ruffolo, 1986, The relationship between alterations in $\alpha_{1}$-adrenoceptor reserve by phenoxybenzamine and benextramine and the sensitivity of cirazoline-induced pressor responses to inhibition by nifedipine, Eur. J. Pharmacol. 126, 297.

Pirola, C.J., A.L. Alvarez, M.S. Balda, S. Finkielman and V.E. Nahmod, 1989, Evidence for cholinergic innervation in dog renal tissue, Am. J. Physiol. 257, F746.

Renzetti, A.R., D. Barone and M. Criscuoli, 1990, High-affinity binding of mequitamium iodide (LG 30435) to muscarinic and histamine $\mathrm{H}_{1}$ receptors, Eur. J. Pharmacol. 182, 413.

Rodrigues de Miranda, J.F., H.L.M. Siero, Y.J.B. Van Megen and C.A.M. Van Ginneken, 1989, Characterization of muscarinic receptors in rat kidney, Trends Pharmacol. Sci. 10 (Suppl.), 109.

Tallarida, R.J.A., A. Cowan and M.W. Adler, 1979, $\mathrm{pA}_{2}$ and receptor differentiation: A statistical analysis of competitive antagonism, Life Sci. 25, 637.
Waelbroeck, M., M. Tastenoy, J. Camus and J. Christophe, 1990, Binding of selective antagonists to four muscarinic receptors $\left(M_{1}\right.$ to $\mathrm{M}_{4}$ ) in rat forebrain, Mol. Pharmacol. 38, 267.

Walder, C.E., C. Thiemermann and J.R. Vane, 1991, The involvement of endothelium-derived relaxing factor in the regulation of renal cortical blood flow in the rat, Br. J. Pharmacol. 102, 967.

Wess, J., G. Lambrecht, E. Mutschler, R.M. Brann and F. Dörje, 1991, Selectivity profile of the novel muscarinic antagonist UH$\mathrm{AH} 37$ determined by the use of cloned receptors and isolated tissue preparations, Br. J. Pharmacol. 102, 246.

Wolf-Pflugmann, M., G. Lambrecht, J. Wess and E. Mutschler, 1989, Synthesis and muscarinic activity of a series of tertiary and quaternary guvacine esters structurally related to arecoline and arecaidine propargyl ester, Arzneim. Forsch./Drug Res. 39, 539.

Yamada, S., H.I. Yamamura and W.R. Roeske, 1986, Effect of chemical sympathectomy with 6-hydroxydopamine on $\alpha$ - and $\beta$ adrenoceptors and muscarinic cholinoceptors in rat kidney, Eur. J. Pharmacol. 121, 345.

Zorn, S.H., R.S. Duman, A. Giachetti, R. Micheletti, E. Giraldo, P. Krogsgaard-Larsen and S.J. Enna, 1987, (R)-Nipecotic acid ethyl ester: $A$ direct-acting cholinergic agonist that displays greater efficacy at $M_{2}$ than at $M_{1}$ muscarinic receptors, J. Pharmacol. Exp. Ther. 242, 173. 